\title{
СПОСОБИ ПЕРЕДАЧІ \\ ІНФІНІТИВА ТА ІНФІНІТИВНИХ КОМПЛЕКСІВ У ПЕРЕКЛАДІ ХУДОЖНЬОГО ТЕКСТУ
}

У статті розглянуто питання відтворення інфінітива та його комплексів у перекладі художнього тексту. Мета роботи - встановити кореляцію між різними чинниками, щзо обумовлюють перекладацькі стратегії для передачі иієї граматичної форми. Найбільш частотним способом перекладу з англійської є граматичний аналог в українській і російській мовах. Використовують й інші варіанти відтворення інфінітива: особова форма дієслова, підрядне речення та граматична заміна частин мови. Переклад інфінітивних комплексів найчастіше супроводжується декомпресією. Установлено, що спосіб відтворення інфінітива залежить передусім не від його синтаксичної функції, а від тексичного наповнення речення, безпосередніх контекстуальних партнерів інфінітива та правил сполучуваності.

Ключові слова: інфінітив, інфінітивний комплекс, граматичний аналог, декомпресія, переклад.

Yarovenko L., Boldyreva A. Ways of Reproducing Infinitive and Infinitive Complexes in a Literary Text Translation. The article focuses on the problem of reproducing the infinitive and its complexes in the translation of a literary text. The purpose of the work is to establish a correlation between different factors that determine translation strategies in the transfer of this grammatical category. This study was performed on the material of D. Brown's novel "The Da Vinci Code" and its translations into Ukrainian and Russian. 530 cases of infinitive use and 108 infinitive complexes are chosen from the text of the novel by random selection. All word usages of the infinitive are divided according to their syntactic functions in the sentence and their versions of translation are analyzed. The analysis of the actual material shows the highest frequency of the infinitive in the function of the compound verbal predicate, which is $46 \%$ of the total. The second most frequent function is the-one of an adverbial modifier of purpose (21\%). The infinitive in the function of an attribute is used in 17\% of all cases. The infinitive in other functions has a lot lower frequency. Translators use all possible ways of reproducing the infinitive, but their frequency within each method varies. Thus, the most commonly used method of translation is a grammatical analogue in both translations. Other ways of rendering the infinitive are - the finite form of the verb, subordinate clause and grammatical replacement of parts of speech. A few cases of omission have been registered, as well. Translators resort not only to grammatical transformations, but also to lexical and lexicalgrammatical transformations - modulation and antonymous translation. All these 
transformations are carried out in order to achieve the adequacy of translation and correspondence to the norms of the target languages. When translating infinitive complexes, decompression is most commonly observed. The analysis of the ways of reproducing the infinitive in two translations shows that the way of its translation, first of all, depends on the lexical content of the sentence, the immediate contextual partners of the infinitive and also the rules of compatibility. The function of the infinitive is of a lesser significance in choosing the translation method. Though the dominant role in the reproduction of the infinitive is played by objective factors of the translation process, the importance of the translator's personality in decision-making cannot be disregarded, as demonstrated by comparative analysis of Ukrainian and Russian translations.

Key words: infinitive, infinitive complex, grammatical analogue, transformation, decompression, translation.

\section{Вступ}

Хоча англійський інфінітив має граматичний аналог у цільових мовах, цей збіг є частковим. Інфінітив вихідної мови (BM) значно більше репрезентативний за кількістю форм, також він відрізняється і за спектром функцій, тому всі ці розбіжності не можуть не викликати деякі труднощі в процесі його відтворення в мові перекладу (МП). Ще більш проблемними для перекладу $є$ інфінітивні комплекси, які не мають прямих граматичних відповідників, що ускладнює процес перекладу.

Усі труднощі, що трапляються під час перекладу інфінітива та його комплексів, зумовлюють необхідність деталізації й удосконалення методології їх відтворення в МП. На наш погляд, інтерес до теоретичного й практичного дослідження інфінітива викликають такі питання, як співвідношення об'єктивних та суб'єктивних чинників у процесі його перекладу, залежність способу перекладу від його синтаксичної функції в реченні, від лексичного оточення інфінітива, а також від стильової приналежності тексту. Усі ці аспекти передачі інфінітива в МП потребують детального висвітлення, що й зумовлює актуальність цього дослідження.

Інфінітив як одна $з$ найбільш уживаних неособових форм англійського дієслова схарактеризовано в численних монографіях, підручниках і статтях під різними кутами зору. Граматичні ознаки інфінітива, його двоїста природа, форми та синтаксичні функції в реченні знайшли висвітлення в працях таких учених, як Г. В. Верба й Л. Г. Верба (Верба, \& Верба 2004), К. Н. Качалова й Є. Є. Ізрайлевіч 
(Качалова, \& Израилевич, 2003), В. Л. Каушанська (Каушанская, 2008), М. А. Ганшіна й Н. М. Василевська (Ганшина, \& Василевская, 1964) та ін. Запропоновані класифікації функцій інфінітива практично збігаються в усіх авторів, за винятком двох - прямого додатка й частини складеного дієслівного присудка. У такому вживанні досліджувана форма сполучається з дієсловами різних семантичних груп і входить до складу різних граматичних моделей, які мовознавці неоднаково співвідносять з інфінітивом.

Крім граматичної природи інфінітива та його комплексів, значний інтерес викликає проблематика його відтворення в МП. Такі вчені, як I. В. Корунець (Корунець, 2003), В. І. Карабан (Карабан, 2001), В. Н. Комісаров (Комиссаров, 1990), Н. К. Яшина (Яшина, 2016) та ін. розглядають способи перекладу інфінітива залежно від його функції в реченні на матеріалі різних функціональних стилів. Вони також указують на труднощі, що виникають у процесі відтворення всіх інфінітивних зворотів. Уважаємо, що є деякі аспекти перекладу інфінітива та його комплексів потребують подальшого вивчення, а саме: застосування різних перекладацьких трансформацій (граматичних, лексичних і лексико-граматичних) для передачі інфінітива та зворотів; кореляція об’єктивних і суб'єктивних чинників та вплив контексту на перекладацьке рішення.

Мета цієї роботи - встановити кореляцію між різними чинниками, що обумовлюють перекладацькі стратегії для передачі граматичної форми інфінітива; іiі завдання: 1) виявити збіги й розбіжності в процесі перекладу інфінітива та його комплексів у різномовних текстах; 2) класифікувати способи перекладу інфінітива й інфінітивних комплексів з англійської мови українською та російською.

\section{Методи дослідження}

У роботі використовуємо такі методи наукового дослідження: порівняльно-зіставний, який спрямовано на встановлення збігів і розбіжностей у репрезентації інфінітива в зіставлюваних мовах; кількісний, що дає змогу виявити частотні характеристики англійського інфінітива в різних функціях у вихідному тексті; дескриптивний, що передбачає сукупність процедур інтерпретації й опису досліджуваної граматичної одиниці, та метод випадкової вибірки для роботи з ілюстративним матеріалом. 


\section{Виклад основного матеріалу}

У процесі перекладу іншомовних текстів фахівець може зіткнутися з багатьма труднощами. Це зумовлено тим, що між різними мовами, окрім лексичних, наявні й значні граматичні відмінності, спричинені особливостями їхньої граматичної системи. Тому для належного відтворення іншомовних текстів перекладачеві потрібно правильно аналізувати граматичну структуру іншомовних речень і конструювати їхні відповідники з огляду на мовні норми та жанр перекладу (літературний, переклад науково-технічних, публіцистичних текстів тощо). Передача інфінітива та його оточення значною мірою залежить від типу тексту, у якому він функціонує. Наприклад, у процесі перекладу художнього твору необхідно передати не тільки семантику одиниць оригіналу, а також його літературні цінності. Тому стильова приналежність тексту значною мірою обумовлює перекладацькі стратегіï, що й продемонстровано в цьому досліджені під час аналізу практичного матеріалу.

Однією з актуальних проблем сьогодення є труднощі, що виникають у перекладі англійського інфінітива. Інфінітив $є$ багатофункціональним як в українській, так і в англійській мовах. Однак кількість форм інфінітива й можливості їх використання в обох мовах відрізняються, що викликає складнощі під час перекладу. Зокрема, в українській і російській мовах немає форм Continuous, Perfect и Perfect Continuous. Крім того, англійський інфінітив виконує низку функцій, деякі з яких не характерні для української неозначеної форми дієслова.

Подвійна природа інфінітива спричиняє деякі труднощі для перекладу його українською мовою, оскільки, з одного боку, наявність відповідної неособової форми дієслова в українській мові значно полегшує процес перекладу цієї конструкції, а з другого, - різноманітність інфінітивних форм та широка парадигма синтаксичних функцій не дають змогу постійно використовувати дослівний переклад і потребують від перекладача здійснення граматичного чи лексико-граматичного перетворення всього речення чи його частини (Яшина, 2016: 64). Усі ці перекладацькі прийоми дають змогу точно передати смислове значення інфінітива та його зворотів відповідно до норм цільової мови. 
На матеріалі роману Д. Брауна «Код да Вінчі» автори цієї наукової розвідки проаналізували функціональні особливості інфінітива й інфінітивних комплексів та способи їх відтворення в українському й російському перекладах. Методом випадкової вибірки з тексту роману було відібрано 530 прикладів уживання інфінітива та розподілено їх відповідно до функцій у реченні за класифікацією К. Н. Качалової та Є. Є. Ізрайлевіча, а також 108 прикладів інфінітивних комплексів. Зіставний аналіз двох перекладів дав змогу простежити збіги й розбіжності в декодуванні інфінітива та його контекстуального оточення двома перекладачами.

Аналіз фактичного матеріалу продемонстрував, що найчастіше в тексті роману інфінітив уживається у функції частини складеного дієслівного присудка (46\%). Така висока частотність інфінітива саме в цій функції може бути пояснена його сполучуваністю з дієсловами різних семантичних груп та вживанням в складі різних граматичних моделей. У процесі його відтворення в цій функції перекладачі в основному використовували такі варіанти: граматичний аналог (інфінітив) і дієслово в особовій формі. Також у процесі перекладу вони вдавалися до граматичних трансформацій: заміни частин мови й типу речення. У переважній більшості випадків інфінітив ВМ перекладено інфінітивом в МП:

He was trapped, and the doors could not be reopened for at least twenty minutes (Brown, 2003: 5).

Він у пастиі, і двері неможливо буде відчинити ще принаймні двадиять хвилин (Браун, 2010: 7).

Он был в ловушке, двери не откроют еще минут двадиять (Браун, 2005: 14).

Переклад пасивного інфінітива ВМ здійснено різними способами: в українському варіанті використано його граматичний аналог, а в російському - дієслово в особовій формі.

Найбільший інтерес викликають випадки, коли перекладачі використовують граматичні трансформації, виходячи з умов контексту й свого сприйняття предметної ситуації:

You'll be shocked to learn what anomalies Da Vinci included here (Brown, 2003: 236).

Ви будете вражені, коли почуєте, які дивні речі да Вінчі тут умістив (Браун, 2010: 240). 
Вы удивитесь, узнав, ито некоторые странности в рисунках и картинах Леонардо сознательно обходились учеными и искусствоведами (Браун, 2005:257).

Український перекладач удається до декомпресії: інфінітив відтворено особовою формою дієслова в складі підрядного речення часу. В російському перекладі інфінітив передано за допомогою дієприслівника.

Також було зафіксовано нечисленні випадки заміни частин мови:

The line began to ring (Brown, 2003: 52).

Пімли гудки (Браун, 2010: 57).

Раздались гудки (Браун, 2005: 62).

У обох перекладах, крім граматичної заміни частин мови (інфінітив трансформовано в іменник), можна також спостерігати лексичну трансформацію - смисловий розвиток.

Другим за частотністю використання став інфінітив у функції обставини мети (21\%). У процесі перекладу інфінітива в цій функції частіше всього спостерігаємо декомпресію: просте речення оригіналу трансформується в складнопідрядне мети зі сполучниками «аби» й «щоб», однак трапляються й інші опції:

Christianity honored the Jewish Sabbath of Saturday, but Constantine shifted it to coincide with the pagan's veneration day of the sun (Brown, 2003: 233).

Спочатку святим днем християни вважали єврейсвкий шабат, тобто суботу, але Костянтин пересунув його, щоб він збігся з поганським днем Сония (Браун, 2010: 241).

Вообще-то изначально христиане считали таким днем еврейский шаббат - субботу, но Константин сдвинул его в пользу почитаемого язычниками дня Солнца (Браун, 2005: 253).

Українською перекладач відтворює інфінітив дієсловом в особовій формі в складі підрядного речення мети зі сполучником “щоб”, а в російському перекладі інфінітив трансформовано в іменник з прийменником, тобто фіксуємо заміну частин мови, але не спостерігаємо декомпресії, яку застосовано в українському перекладі.

У наступному реченні використано два інфінітиви у функції обставини мети. В українському перекладі один із них відтворено за допомогою іменника 3 прийменником, а другий - особовою формою дієслова в підрядному реченні мети. У російському перекладі один 
інфінітив перетворено також на іменник з прийменником, а другий вилучено з перекладу. Крім того, в обох варіантах застосовано лексико-граматичну трансформацію - антонімічний переклад.

Historians still debated whether Da Vinci wrote this way simply to amuse himself or to keep people from peering over his shoulder and stealing his ideas (Brown, 2003: 301).

Історики досі сперечаються, чи да Вінчі писав так просто задля розваги, чи тому, щьо не хотів, аби хтось викрав у нього ідеї (Браун, 2010: 314).

Историки по сию пору спорят о том, делал ли это да Винчи для собственного развлечения или же для того, чтобь люди, заглядывающие емучерез плечо, не крали у него идеи (Браун, 2005: 322).

Інфінітив у функції означення також має досить високу частотність (17\%). Найбільш поширеними варіантами перекладу є інфінітив зі збереженням синтаксичної основи англійського речення, а також з перебудовою простого речення на складне з підрядним означальним:

Langdon sensed his host was a hard man to please (Brown, 2003: 21).

Ленгдон відчув, що Фаш - людина, якій важко догодити (Браун, 2010: 23).

Ленгдон понял, что этому человеку трудно угодить (Браун, 2005: 27).

В обох перекладах атрибутивний інфінітив відтворено граматичним аналогом, але в українському перекладі відбувається декомпресія, що супроводжується заміною типу речення. У російському перекладі декомпресію не спостерігаємо - зберігається тип речення BM. Крім того, перекладачі вдавалися до перестановки та заміни частин мови (прикметник ВМ відтворено прислівником МП). Крім цих способів перекладу, було зафіксовано й інші:

She was gone now, and Fache still had cards to play (Brown, 2003: 72).

Тепер вона пішла, а Фаш ще має кілька козирів на руках (Браун, 2010: 77).

Сейчас она ушла, и Фаш еще не разыграл свою главную карту (Браун, 2005: 82).

У процесі відтворення інфінітива обидва перекладачі вдалися до лексичної трансформації - модуляції. В українському перекладі інфінітив трансформовано в іменник 3 прийменником, 
а в російському - перетворено на особову форму дієслова в минулому часі з використанням антонімічного перекладу. На наш погляд, обидва переклади є вдалими відповідно до норм МП та відтворення семантики одиниць ВМ. Водночас вони демонструють роль особистості фахівця в процесі перекладу.

I have a favor to ask you (Brown, 2003: 411).

Маю до вас прохання (Браун, 2010: 423).

Я хочу попросить вас об одолжении (Браун, 2005: 457).

В українському перекладі спостерігаємо заміну частин мови, а в російському - інфінітив передано його граматичним аналогом.

Також було зафіксовано декілька прикладів передачі інфінітива за допомогою дієприкметникових зворотів та його вилучення.

Аналіз перекладу атрибутивного інфінітива показує, що найбільш частотним способом перекладу є неозначена форма дієслова (інфінітив).

Інфінітив у функції обставини наслідку (результату) становить 7\%. Найчастіше під час перекладу просте речення ВМ трансформується в складнопідрядне в МП.

Langdon sighed, too tired to play games (Brown, 2003: 21).

Ленгдон зітхнув, він надто втомився, щоб далі грати в ігри (Браун, 2010: 23).

Ленгдон вздохнул, ему начали надоедать эти игры (Браун, 2005: 29).

Інфінітив ВМ в українському перекладі передано його граматичним аналогом, а в російському вилучено з перекладу. Також $є$ значні розбіжності в синтаксичних структурах: в українському перекладі просте речення оригіналу трансформовано в складнопідрядне, а в російському - у безсполучникове.

У цій функції інфінітив може стояти не тільки після прислівників enough, so, too, а й після присудків. У такій позиції він виражає дію, що є логічним продовженням тієї, яку називає присудком. Перекладають таке речення з використанням однорідних членів речення:

Startled, Langdon glanced up to find Fache's eyes on him in the reflection (Brown, 2003 :25).

Ленгдон здивовано підвів очі і піймав у відображенні погляд чорних очей Фаша (Браун, 2010: 28). 
Лэнгдон вздрогнул, поднял глаза и поймал в отражении взгляд черных глазок капитана (Браун, 2005: 33).

Подальша дія завжди передається в процесі перекладу паралельною конструкцією, що продемонстровано в прикладах обома мовами.

Було зафіксовано 4\% використання інфінітива у функції прямого додатка. У всіх проаналізованих прикладах інфінітив перекладено українською та російську мову однаково - початковою формою дієслова (інфінітивом) в тій самій функції:

The next day, her grandfather taught her to ride, running beside her down the walkway (Brown, 2003: 111).

Наступного дня дідусь учив ї̈ ӥзити на велосипеді, увесь час біг алеєю поряд (Браун, 2010: 115).

На следующий же день дед начал учить ее кататься на велосипеде, бежал рядом с ней по дорожке, придерживая седло (Браун, 2005: 124).

Слід зазначити, що в цій функції інфінітив уживається лише в теперішньому часі й активному стані. Інфінітив розглядається як прямий додаток у тих випадках, коли він виражає дію, що ії виконує не та особа, яку називає підмет, а та, на яку вказує додаток. Якщо ж інфінітив виражає дію, виконувану підметом, то він $є$ частиною складеного дієслівного присудка (Качалова, Ізрайлевич, 2003: 230).

Інфінітив у функції частини складеного іменного присудка має досить низьку частотність, що становить 3\%. Він сполучається з дієсловом-зв'язкою “to be”, яке може перекладатися дієсловом “бути” у відповідній формі або вилучатися з перекладу. Сам інфінітив відтворюється за допомогою граматичного відповідника чи іншим способом.

Their true goal in the Holy Land was to retrieve the documents from beneath the ruins of the temple (Brown, 2003 : 158).

Їхньою справжньюю місією на Святій землі було добути документи 3-під останків храму (Браун, 2010: 167).

Истинною иелью их пребывания на Святой земле было извлечение документов из-под развалин храма (Браун, 2005: 173).

Як бачимо, в українському тексті використано найбільш поширений варіант перекладу - граматичний еквівалент. Російський перекладач удався до граматичної заміни частин мови: інфінітив було 
відтворено віддієслівним іменником. Такий спосіб передачі інфінітива в цій функції можливий, але менш розповсюджений.

Інфінітив у функції підмета становить $2 \%$ від загальної кількості вживань інфінітива. У всіх зафіксованих випадках застосування інфінітива у функції підмета його було перекладено інфінітивом.

To ask you to stay awake is too much (Brown, 2003: 89).

I просити, щзб ви залишились зі мною, було б уже занадто (Браун, 2010: 93).

И просить остаться было бы слишком (Браун, 2005: 101).

Спираючись на теоретичні засади щодо способів перекладу англійського інфінітива й проаналізований практичний матеріал, ми класифікували варіанти його передачі в українському та російському перекладі роману Д. Брауна «Код да Вінчі» та отримали такі кількісні результати:

- за допомогою граматичного аналога (укр. переклад - 57\%; рос. $51 \%)$;

- за допомогою особової форми дієслова (укр. переклад - 23\%; poc. $-28 \%)$;

- за допомогою підрядного речення (укр. переклад - 13 \%; рос. $16 \%)$

- за допомогою заміни частин мови (укр. переклад - 4\%; рос. - 2\%);

- шляхом вилучення (укр. переклад - $2 \%$; рос. - $3 \%$ ).

Порівняльний аналіз двох перекладів продемонстрував незначні розбіжності в кількісних даних за способами перекладу інфінітива. Водночас випадки повного збігу в передачі інфінітива в кожній функції одночасно були нечисленні, що й підтверджує чинник особистості перекладача, який значно впливає на вибір варіанту перекладу одиниці ВМ. Найбільший інтерес в аспекті перекладу представляють інфінітивні звороти, яких немає в граматичних системах української та російської мов, що може викликати труднощі в процесі відтворення через відсутність прямих граматичних відповідників.

У тексті роману було зафіксовано три інфінітивні конструкції з різною частотністю їх використання.

Найбільшу частотність у тексті роману має суб'єктний інфінітивний зворот (53 випадки), у якому англійський інфінітив може вживатися у всьому різноманітті своїх граматичних форм, що й було зафіксовано в цьому дослідженні. Детально способи його передачі 
розглядає I. В. Корунець. Зокрема, до основних способів його відтворення він відносить: 1) використання неозначено-особового речення; 2) використання односкладного неозначено-особового речення в поєднанні з підрядним з'ясувальним; 3) використання безособового речення з формами на: -но, -то; 4) використання вставних слів або вставних словосполучень, що містяться в означено-особових реченнях МП; 5) використання модальних слів в означено-особовому реченні (Корунець, 2003). У досліджуваних перекладах було зафіксовано декілька способів його відтворення:

The late French president was said to have suffered from a «Pharaoh complex» (Brown, 2003: 18)

Подейкували, щзо ией нині покійний президент Франції страждав так званим фараоновим комплексом (Браун, 2010: 21).

Говорили, что этот покойный ныне президент Франиии страдал так называемым бараоновым комплексом (Браун, 2005: 27).

Обидва перекладачі вдалися до граматичної трансформації - заміни типу речення. Головне речення в складі підрядного з'ясувального представлено односкладним неозначено-особовим.

Actually the keystone is believed to have been created by the Priory sometime in the past couple of decades (Brown, 2003: 204).

Насправді вважається, що Пріорат створив наріжний камінь в останні кілька десятків років (Браун, 2010: 217).

Бытует мнение, что краеугольный камень был создан несколько десятилетий назад одним из членов Приората (Браун, 2005: 233).

У обох перекладах спостерігаємо декомпресію, унаслідок якої просте речення ВМ трансформується в складнопідрядне з'ясувальне в МП. В українському перекладі головне речення представлено безособовим, і пасивний перфектний інфінітив перекладено особовою формою дієслова минулого часу в активному стані. У російському перекладі головне речення - особове, а інфінітив передано особовою формою дієслова минулого часу в пасивному стані.

Значну кількість також становлять випадки збереження структури речення оригіналу під час перекладу цього комплексу, особливо з такими дієсловами, як "to seem”, “to appear":

Sophie didn't seem to hear (Brown, 2003: 138).

Софі не відповідала (Браун, 2010: 146).

Софи, видно, не сльшиала его слов (Браун, 2005: 159). 
У обох перекладах цій зворот передано простим реченням, але сам інфінітив по-різному декодовано: російський переклад $є$ практично калькою оригіналу, а в українському - перекладач удається до смислового розвитку. В обох реченнях інфінітив відтворено особовою формою дієслова в минулому часі.

Як показав аналіз усіх випадків перекладу, як український, так і російський перекладач передають суб’єктний інфінітивний зворот за допомогою односкладного неозначено-особового речення в поєднанні з підрядним з'ясувальним, за допомогою означено-особового речення зі вставними словами або навіть двоскладного простого.

Другим за частотністю $є$ об'єктний інфінітивний зворот (47 випадків). Під час його перекладу спостерігаємо тенденцію до використання декомпресії: англійське просте речення трансформується в українське складнопідрядне з підрядним з'ясувальним, що приєднується до головного сполучними словами “що”, “як”, “щоб”, “ніби”, “мов", “наче", “чи":

He had expected the keystone to be a map, or a complex series of directions, perhaps even encoded (Brown, 2003: 392).

Він очікував, щзо ие буде якась карта чи складний набір вказівок, можливо, навіть закодованих (Браун, 2010: 423).

Он считал, что краеугольный камень окажется картой или же комбинацией указаний направления, возможно, даже закодированной (Браун, 2005: 485).

Обидва переклади демонструють трансформації простого речення ВМ у складнопідрядне в МП.

Також слід звернути увагу на те, що в тому разі, коли об’єктний інфінітивний комплекс стоїть після дієслова “feel” (відчувати), найчастіше в перекладі фіксуємо просте речення з певними лексичними трансформаціями, що й підтверджує такий приклад:

Fache felt his teeth clench in rage (Brown, 2003: 49).

Фаш від люті зиіпив зуби (Браун, 2010: 56).

Фаши в ярости стиснул зубы (Браун, 2005: 65).

У обох перекладах інфінітив передано особовою формою дієслова, а також зберігається тип речення оригіналу.

У відтворенні об'єктного інфінітивного комплексу в обох перекладах домінує спосіб трансформації простого речення ВМ у складнопідрядне з'ясувальне в МП. 
Комплекс “інфінітив з прийменником for” має досить низьку частотність (8 випадків), і його переклад передусім залежить від контексту речення:

I swear, sir, there is no way for me to know that (Brown, 2003: 305).

Присягаюся, капітане, иъого знати я не можу (Браун, 2010: 327). Клянусь, сэр, я этого не знаю (Браун, 2005: 346).

У обох перекладах спостерігаємо декомпресію: інфінітивний комплекс розгортається в самостійне речення завдяки трансформації додатка в підмет. Інфінітив в українському перекладі передано аналогом, у російському - особовою формою. Перекладачі вдаються до двох типів замін: заміни типу речення і його членів.

Як показав аналіз усіх прикладів використання цього комплексу, перекладачі віддають перевагу граматичній трансформації - заміні типу речення в процесі перекладу, однак можливе також збереження синтаксичної структури оригіналу.

\section{Висновки}

За результатами проведеного дослідження ми дійшли таких висновків:

1. У тексті роману інфінітив найчастіше вживається у функціях частини складеного дієслівного присудка, обставини мети та означення.

2. Кількісний аналіз продемонстрував, що в ієрархії способів відтворення інфінітива в обох досліджуваних мовах домінує переклад граматичним аналогом. Решту типів зафіксовано в такій кількісній послідовності: особова форма дієслова, підрядне речення, заміна частин мови та вилучення.

3. Під час перекладу інфінітива фахівці вдаються до різних трансформацій з метою досягнення еквівалентності й відповідності нормам МП. Крім граматичних замін, вони також здійснюють лексичні й лексико-граматичні трансформації: смисловий розвиток та антонімічний переклад. Відтворення інфінітивних комплексів найчастіше супроводжується декомпресією речення ВМ в МП.

4. Переклад інфінітива обумовлено передусім його контекстуальним оточенням, безпосередніми контекстуальними партнерами й правилами сполучуваності слів у реченні, а не його синтаксичною 
функцією. Стильова приналежність тексту ВМ також впливає на перекладацькі стратегії.

5. Зіставний аналіз двох перекладів дає змогу простежити значущість, крім об'єктивних чинників, суб'єктивних факторів у процесі перекладу. Випадки повного збігу за способами передачі інфінітива у двох перекладах одночасно мають досить низький відсоток, що $є$ яскравою ілюстрацією значного впливу особистості перекладача на відтворення не лише інфінітива, але й усіх складників тексту оригіналу.

\section{ЛІТЕРАТУРА}

1. Верба, Г., \& Верба, Л. (2006). Граматика сучасної англійської мови. Київ: ТОВ «ВП Логос-М». 2. Ганшина, М., \& Василевская, Н. (1964). Практическая грамматика английского языка. Москва: Высш. шк. 3. Карабан, В. (2004). Переклад англійської наукової і технічної літератури. Вінниця: Нова книга. 4. Каушанская, В. (2008). Грамматика английского языка. Москва: Айрис-пресс. 5. Качалова, К., \& Израилевич, Е. (2003). Практическая грамматика английского языка. Киев: Методика. 6. Комиссаров, В. (1990). Теория перевода (лингвистические аспекты). Москва: Высш. шк. 7. Корунець, І. (2008). Вступ до перекладознавства. Вінниця: Нова книга. 8. Яшина, Н. (2016). Учебное пособие по переводу. Владимир: Изд-во ВлГУ.

\section{ДЖЕРЕЛА}

9. Brown, D. (2003). The Da Vinci Code. New York: Random House. 10. Бpaун, Д. (2010). Код да Вінчі (А. Кам’янець, перекл.) Харків: Книжк. клуб «Клуб Сімейного Дозвілля». 11. Браун, Д. (2005). Код да Винчи (Н. В. Рейн, перев.). Москва: «Изд-во АСТ».

\section{REFFERENCES}

1. Verba, G., \& Verba, L. (2006). Gramatika suchasnoi angliiskoi movy [Grammar of modern English]. Kyiv: TOV «VP Lohos-M» [in Ukrainian]. 2. Ganshina, M., \& Vasilevskaya, N. (1964). Prakticheskaya grammatika angliyskogo yazyika [Practical English grammar]. Moskva: Vyssh. shk. [in English]. 3. Karaban, V. (2004). Pereklad angliiskoi naukovoi i tekhnichnoi literatury. [Translation of English scientific and technical literature]. Vinnitsya: Nova kniga [in Ukrainian]. 4. Kaushanskaya, V. (2008). Grammatika angliyskogo yazyika [English grammar]. Moskva: Ayris-press [in English]. 5. Kachalova, K., \& Izrailevich, E. (2003). Prakticheskaya grammatika angliyskogo yazyika [Practical English grammar]. Kiev: Metodika [in Russian]. 6. Komissarov, V. (1990). Teoriya perevoda [Translation theory (linguistic aspects)]. Moskva: Vyssh. shk. [in Russian]. 7. Korunets, I. (2008). Vstup do perekladoznavstva [Introduction into Translation Studies]. Vinnitsya: Nova kniga [in Ukrainian]. 8. Yashina, N. (2016). Uchebnoe posobie po perevodu [Translation tutorial]. Vladimir: Izd-vo VlGU [in Russian]. 


\section{DZHERELA - SOURCES}

9. Brown, D. (2003). The Da Vinci Code. New York: Random House [in English]. 10. Braun, D. (2010). Kod da Vinchi [The Da Vinci Code]. (A. Kamiyanets, trans). Kharkiv: Knizhk. klub «Klub Simeynogo Dozvillya» [in Ukrainian]. 11. Braun, D. (2005) Kod da Vinchi [The Da Vinci Code]. (N. Reyn, trans.) Moskva: «Izd-vo AST» [in Russian].

Яровенко Людмила Степанівна - кандидат філологічних наук, доцент, доцент кафедри теорії та практики перекладу, Одеський національний університет ім. I. I. Мечникова; Французький бульвар, 24/26, м. Одеса, 65000, Україна.

Tel.:+38-095-667-61-73

E-mail: yarovenkoludmila@ukr.net

http://orcid.org /0000-0001-6199-0974

Yarovenko Liudmyla Stepanivna - Candidate of Philological Sciences (Ph.D.), Docent, Associate Professor at the Department of Theory and Practice of Translation, I. I. Mechnykov Odessa National University; 24/26 Frantsuzkyi Blvd., Odessa, 65000, Ukraine.

Болдирева Анжела Євгеніївна - кандидат філологічних наук, доцент, доцент кафедри теорії та практики перекладу, Одеський національний університет ім. I. І. Мечникова; Французький бульвар, 24/26, м. Одеса, 65000, Україна.

Tel.: +38-095-147-04-49

E-mail: annelina2207@gmail.com

http//orcid.org/0000-0003-4327-3773

Boldyreva Anzhela Yevgeniivna - Candidate of Philological Sciences (Ph.D.), Docent, Associate Professor at the Department of Theory and Practice of Translation, I. I. Mechnykov Odessa National University; 24/26 Frantsuzkyi Blvd., Odessa, 65000, Ukraine.

Надійшла до редакції 5 березня 2021 року

\section{CITATION}

ДСТУ 8302:2015: Яровенко Л. С., Болдирева А. Є. Способи передачі інфінітива та інфінітивних комплексів у перекладі художнього тексту. Лінгвістичні дослідження: зб. наук. пр. Харк. нац. пед. ун-ту імені Г. С. Сковороди. Харків, 2021. Вип. 54. Ч. II. C. 209-223. DOI: https://doi.org/10.34142/23127546.2021.54.2.19

APA: Яровенко, Л. С., \& Болдирева, А. Є. (2021). Способи передачі інфінітива та інфінітивних комплексів у перекладі художнього тексту. Лінгвістичні дослідження, 54 (II), 209-223. DOI: https://doi.org/10.34142/23127546.2021.54.2.19 